\title{
Response of Tomato Plants to Foliar Application of Humic, Fulvic Acid and Chelated Calcium
}

\author{
S. Abou El Hassan and M.E. Husein* \\ Central Lab of Organic Agriculture, Agricultural Research \\ Center, and *Soil Dept., Faculty of Agriculture, Cairo Univ., \\ Egypt.
}

TFLUENCE of humic, fulvic acid and calcium foliar application on growth, yield and quality of tomato (H9663 hybrid) was investigated during 2013 and 2014 summer seasons. The experiment was designed in completely randomized block at the Experimental Station, Faculty of Agriculture, Cairo University, Giza, Egypt. Solutions of humic acid $(0.4 \%)$, fulvic acid (4\%) and chelated calcium $(0.25 \%)$ were applied as foliar sprays alone or in combinations on tomato plants at four times after two, four, six and eight weeks from transplanting. Vegetative growth parameters and nutrients content $(\mathrm{N}$, $\mathrm{P}, \mathrm{K}$ and $\mathrm{Ca}$ ) of tomato plants as well as yield, fruits quality and incidence percentage of blossom end rot in fruits were investigated on treated and untreated plants. Results indicated that the foliar application of humic, fulvic acid and calcium either individual or in combinations increased vegetative growth, yield, fruit quality and decreased the incidence of blossom end rot in tomato fruits.

Keywords: Humic acid, Fulvic acid, Calcium, Foliar application, Blossom end rot, Tomato

Tomato (Solanum lycopersicum) is one of the most important and popular fruit vegetable crops grown in many countries. The total cultivated area in Egypt was 515225 feddans (feddan equal 0.4 hectare), produced about 8571050 tons on annual basis with an average of productivity 16.636 tons/feddan in season (Ministry of Agriculture and Land_Reclamation, 2013). It has many nutrition values such as high content of potassium, vitamins $\mathrm{C}$ and $\mathrm{E}$, flavonoids, chlorophyll, $\beta$-carotene, and lycopene (Jones, 2008). Increasing the production of tomato with high quality is considered an important aim and this aim could be achieved through using the foliar application of humic, fulvic acid and calcium.

Humic substances such as humic acid, fulvic acid are the major components (65$70 \%$ ) of soil organic matter, increase plant growth enormously due to increasing cell membrane permeability, respiration, photosynthesis, oxygen and phosphorus uptake and supplying root cell growth (Cacco \& Dell Agnolla, 1984, Russo \& Berlyn, 1990 and Fahramand et al., 2014). Foliar spraying of humic acid promoted growth in many plants such as tomato, cotton and grape (Brownell et al., 1987). Karakurt et al. (2009) reported that humic acid application affected pepper growth and fruit characteristics and had positive influence on quantitative and qualitative of pepper plant. Ameri and Tehranifar (2012) investigated that spraying of humic acid on strawberry plants enhanced nutrient uptake ( $N, P$ and $K)$ and 
physiological characteristics of fruits. Also, HosseiniFarahi et al. (2013) suggested that foliar application of humic acid led to improvement of quantitative and qualitative characteristics of strawberry (chlorophyll content, fruit number, total yield of plant, TSS and fruit firmness). Yildirim (2007) mentioned that foliar application of humic acid on tomato plants increased product quantity and quality.

Fulvic acid accelerates cellular division thus stimulates vegetable growth and development as well as increase of cellular energy and regulation of plant metabolism to prevent nitrate compounds from accumulating in plants and increase in resistance to insects and diseases by encouraging tolerance to extreme temperatures such as heat and coldness and many other physical factors (Jackson, 1993). Fulvic acid chelates and binds scores of minerals into a bio-available form used by cells. These trace minerals serve as catalysts to vitamins within the cell. Additionally, fulvic acid is one of the most efficient transporters of vitamins into the cell. Fulvic acid stimulates and balances cells, creating optimum growth and replication conditions (Pardoe et al., 1990). It enhances the permeability of cell membranes (Christman and Gjessing, 1983)._There were research revealed that the treated plants with fulvic acid had significant beneficial effects on roots and shoots (McCarly, 1985) on tomato and (Khang, 2011) on rice and radish. Fulvic acid is particularly preferred in that it allows surrounding stress to decrease, helps absorb other minerals and positively contributes to yield and quality (Bethke et al., 1987).

Calcium is one of the nutrients which are multi-functional in plant physiology and vital for vegetative growth and development (Assmann, 1995 and Marschner, 1995).They are important intracellular messengers, mediating responses to hormones, biotic and abiotic stress signals and a variety of developmental processes (Reddy and Reddy, 2004). In most fruits, firmness retention is an important quality parameter in fresh-cut fruits and vegetable products. The preharvest nutritional status of fruit, especially with respect to calcium, is an important factor affecting potential storage life (Fallahi et al., 1997). Foliar applications of calcium chloride improved fruits quality, delay ripening and retard fungal growth on strawberries (Wojcik and Lewandowski, 2003). Peyvast et al. (2009) reported that foliar application of calcium could increase tomato yield and yield components with high quality. Foliar application of humic acid and calcium alone or in combination improved growth parameters, yield and fruit quality of tomato; in the other hand it decreased the incidence of blossom end rot. The combination treatment was more effective than individual application (Kazemi, 2013). Foliar application of fulvic acid and calcium with trace elements enhances the yield, quality and nutritional status of tomato plants (Yildirim and Unay, 2011).

The present work aims to study the effects of foliar spraying of humic, fulvic acid and calcium alone or in combination on the growth, yield, fruit quality characteristics and blossom end rot incidence of tomato fruits.

Egypt. J. Soil Sci. 56, No. 3 (2016) 


\section{Materials and Methods}

The field trial was conducted during the two growing summer seasons of 2013 and 2014 at the Agricultural Experimental Station, Faculty of Agriculture, Cairo University, El-Giza Governorate, Egypt to investigate the influence of humic, fulvic acid and calcium foliar application on growth, yield and fruits quality of tomato plants. Tomato transplants (H9663 hybrid) were transplanted in the field on 13 and 17 of February in the first and second seasons, respectively. The experimental soil was analyzed according to FAO (1980) and is presented in Table 1.

The soil of the experiment was ploughed after addition of 5 ton commercial compost / feddan and divided into ridges ( $1 \mathrm{~m}$ width and $10 \mathrm{~m}$ length); each plot contained three ridges. The space between plants was $50 \mathrm{~cm}$, one row of plants on each ridge. The chemical analyses of compost are illustrated in Table 2. The drip irrigation system consisted of polyethylene hoses GR $\left(4 \mathrm{l} \mathrm{h}^{-1}\right)$ of $16 \mathrm{~mm}$ in diameter, allocating one hose for each ridge. Irrigation frequency was every 2 days to maintain soil moisture above 50\% according to Qassim and Ashcroft (2002), which is the optimum moisture level of tomato plants.

TABLE 1. The analyses of the experimental soil

\begin{tabular}{|c|c|c|c|c|c|c|c|c|c|c|c|c|c|}
\hline \multirow{2}{*}{$\underset{\%}{\text { Clay }}$} & \multirow{2}{*}{$\begin{array}{c}\text { Silt } \\
\%\end{array}$} & \multirow{2}{*}{$\begin{array}{c}\text { Sand } \\
\%\end{array}$} & \multirow{2}{*}{$\begin{array}{c}\text { Textur } \\
\text { e }\end{array}$} & \multirow{2}{*}{ pH } & \multirow{2}{*}{$\begin{array}{c}E C \\
d S / m\end{array}$} & \multicolumn{4}{|c|}{$\begin{array}{c}\text { Cations } \\
\text { meq/l }\end{array}$} & \multicolumn{4}{|c|}{ Anions meq/l } \\
\hline & & & & & & $\mathrm{Ca}^{++}$ & $\mathbf{M g}^{++}$ & $\mathrm{Na}^{+}$ & $\mathbf{K}^{+}$ & $\mathrm{Co}_{3}^{-}$ & $\mathrm{HCO}_{3}^{-}$ & $\mathrm{Cl}^{-}$ & $\mathrm{SO}_{4}{ }^{=}$ \\
\hline 70.76 & 15.52 & 13.72 & Clay & 7.77 & 0.85 & 1.82 & 0.43 & 3.33 & 0.52 & 0.24 & 1.27 & 2.74 & 2.53 \\
\hline
\end{tabular}

TABLE 2. The chemical analyses of commercial compost

\begin{tabular}{|c|c|c|c|c|c|c|c|}
\hline & EC 1:10 & O.C & O.M & C/N & N & P & K \\
\cline { 5 - 8 } pH 1:5 & dS/m & $(\%)$ & $(\%)$ & Ratio & \multicolumn{3}{|c|}{$\mathbf{( \% )}$} \\
\hline 7.48 & 4.82 & 21.24 & 36.65 & 18.00 & 1.22 & 0.85 & 1.13 \\
\hline
\end{tabular}

All plots received a recommended dose of NPK fertilizers (125 - $45-48 \mathrm{~kg}$ feddan $^{-1}$ ) according to Ministry of Agriculture and Land Reclamation (2009) as ammonium sulfate $(20.5 \% \mathrm{~N})$, phosphoric acid $\left(58 \% \mathrm{P}_{2} \mathrm{O}_{5}\right)$ and potassium sulfate $\left(48 \% \mathrm{~K}_{2} \mathrm{O}\right)$. The fertilizer solutions were injected directly into the irrigation water using a venture injector at two doses weekly. Other recommended agricultural practices were followed as commonly used in the commercial production of tomato.

The individual and combination applications of humic acid (0.4\%), fulvic acid $(4 \%)$ and chelated calcium on amino acids $(0.25 \%)$ solutions were applied as foliar sprays on tomato plants at four times after 2, 4, 6 and 8 weeks from transplanting, while, the control plants untreated. 
The treatments of this experiment were arranged in a completely randomized block design with three replicates.

After 60 days from transplanting, three plants from each replicate were randomly chosen to measure plant length, stem diameter, number of leaves and clusters for plant. Total nitrogen, phosphorous, potassium and calcium were determined in the dry matter of fourth leaf according to Cottenie et al. (1982). Total nitrogen was determined by Kjeldahl method according to the procedure described by FAO (1980). Phosphorus content was determined using spectrophotometer according to FAO (1980). Potassium and calcium content was determined spectrometrically using Phillips Unicum Atomic Absorption Spectrometer as described by FAO (1980). Fresh and dry shoot weight of plants was measured at harvesting.

Total yield for each plot was recorded accumulatively after each harvesting and collected for feddan. The percentage of blossom end rot incidence (BER) was estimated by counting the total number of fruits and fruits showing symptoms of blossom end rot in each treatment. The blossom end rot incidence is expressed as a percentage of total fruits.

Five ripe fruits (fully red color) were selected randomly to measure some fruit characteristics. Fruit firmness was measured by penetrometer (Lfra Texture Analyzer) using a penetrating needle of $1 \mathrm{~mm}$ of diameter, $3 \mathrm{~mm}$ in distance and speed of $2 \mathrm{~mm} / \mathrm{second}$ and the peak of resistance was recorded as $\mathrm{g} \mathrm{mm}^{-2}$. Total soluble solids (TSS) were measured by using a digital Refractometer. Titratable acidity was determined in fresh juice of fruit samples by titration against sodium hydroxide $(\mathrm{Na} \mathrm{OH})$ using phenolphthalein as well as, vitamin $\mathrm{C}$ in fruits according to the described method in AOAC (2005).

Data of the two seasons were arranged and statistically analyzed by the analysis of variance using one way ANOVA with SAS package. Comparison of treatment means was done using Tukey test at significance level 0.05.

\section{Results and Discussion}

The effects on tomato plants growth by treatments are presented in Tables 3 and 4 . The results reveal that foliar application of humic, fulvic acid and calcium individual or in combination significantly increased fresh and dry shoot weight compared to control treatment. The highest values of fresh and dry shoot weight were obtained with plants sprayed mixture of humic, fulvic acid and calcium, whereas the untreated plants produced the lowest value. Similar results were obtained with other vegetative growth parameters (plant length, stem diameter and number of leaves) and number of cluster. This increment in plants growth may be due to a positive effect of humic substances (humic and fulvic acid) that increase cell membrane permeability, respiration, photosynthesis, oxygen and phosphorus uptake and root cells growth. In addition, fulvic acid is one of the most efficient transporters of vitamins into the cell (Christman \& Gjessing 1983;

Egypt. J. Soil Sci. 56, No. 3 (2016) 
Cacco \& Dell Agnolla, 1984; Russo \& Berlyn, 1990; Jackson, 1993 and Fahramand et al., 2014). Also, the good plants growth might be due to a benefit effect of calcium which is multi-functional in plant physiology and vital for vegetative growth and development (Assmann, 1995 and Marschner, 1995). These results are in the same line with those obtained by McCarly (1985), Brownell et al. (1987), Karakurt et al. (2009) and Khang (2011).

TABLE 3. The effect of foliar application of HA, FA and Ca on fresh and dry weight of shoot and stem diameter of tomato plants during 2013 and 2014 seasons

\begin{tabular}{|c|c|c|c|c|c|c|c|c|c|c|c|}
\hline \multirow{3}{*}{$\begin{array}{l}\text { Treatments } \\
\text { Control }\end{array}$} & \multicolumn{3}{|c|}{$\begin{array}{c}\text { Fresh weight } \\
\text { Kg/plant }\end{array}$} & \multicolumn{4}{|c|}{$\begin{array}{l}\text { Dry weight } \\
\text { g/plant }\end{array}$} & \multicolumn{4}{|c|}{$\begin{array}{c}\text { Stem diameter } \\
\mathbf{m m}\end{array}$} \\
\hline & $\begin{array}{c}1^{\text {st }} \\
\text { season }\end{array}$ & \multicolumn{2}{|c|}{$\begin{array}{c}2^{\text {nd }} \\
\text { season }\end{array}$} & \multicolumn{2}{|c|}{$\begin{array}{c}1^{\text {st }} \\
\text { season }\end{array}$} & \multicolumn{2}{|c|}{$\begin{array}{c}2^{\text {nd }} \\
\text { season }\end{array}$} & \multicolumn{2}{|c|}{$\begin{array}{c}1^{\text {st }} \\
\text { season }\end{array}$} & \multicolumn{2}{|c|}{$\begin{array}{c}2^{\text {nd }} \\
\text { Season }\end{array}$} \\
\hline & 2.31 & 2.43 & $\mathrm{e}$ & 330 & $\mathrm{f}$ & 344 & $\mathrm{f}$ & 11.33 & $\mathrm{f}$ & 11.80 & $\mathrm{e}$ \\
\hline Humic acid & 2.80 & 2.89 & $\mathrm{c}$ & 399 & $\mathrm{~cd}$ & 410 & $\mathrm{c}$ & 15.93 & $\mathrm{c}$ & $16.33 \mathrm{~b}$ & $\mathrm{bc}$ \\
\hline Fulvic acid & $2.62 \mathrm{de}$ & 2.76 & $\mathrm{~cd}$ & 377 & de & 390 & de & 14.00 & de & 14.57 & $\mathrm{~cd}$ \\
\hline Calcium & 2.50 & 2.61 & de & 359 & $\mathrm{e}$ & 371 & $\mathrm{e}$ & 13.33 & $\mathrm{e}$ & 13.88 & $\mathrm{~d}$ \\
\hline $\mathrm{HA}+\mathrm{Ca}$ & 2.86 & 3.06 & $\mathrm{~b}$ & 418 & $\mathrm{~cd}$ & 438 & $\mathrm{~b}$ & 16.33 & $\mathrm{c}$ & 16.83 & $\mathrm{~b}$ \\
\hline $\mathrm{FA}+\mathrm{Ca}$ & $2.72 \mathrm{~cd}$ & 2.83 & $\mathrm{c}$ & 389 & $\mathrm{~d}$ & 402 & $\mathrm{~cd}$ & 15.33 & $\mathrm{~cd}$ & $16.00 \mathrm{~b}$ & $\mathrm{bc}$ \\
\hline $\mathrm{HA}+\mathrm{F}$ & 3.19 & 3.57 & $\mathrm{a}$ & 457 & $\mathrm{~b}$ & 513 & $\mathrm{a}$ & 18.33 & $\mathrm{~b}$ & 19.17 & $\mathrm{a}$ \\
\hline $\mathrm{HA}+\mathrm{F}+\mathrm{Ca}$ & 3.55 & 3.72 & $\mathrm{a}$ & 505 & $\mathrm{a}$ & 529 & $\mathrm{a}$ & 21.00 & $\mathrm{a}$ & 21.00 & $\mathrm{a}$ \\
\hline
\end{tabular}

Means followed in same column by similar letters are not statistically different at 0.05 level according to Tukey test.

TABLE 4. The effect of foliar application of HA, FA and Ca on plant length, leaves and clusters number of tomato plants during 2013 and 2014 seasons

\begin{tabular}{|c|c|c|c|c|c|c|c|c|c|c|c|}
\hline \multirow{3}{*}{$\begin{array}{l}\text { Treatments } \\
\text { Control }\end{array}$} & \multicolumn{3}{|c|}{$\begin{array}{c}\text { Plant length } \\
\text { cm }\end{array}$} & \multicolumn{4}{|c|}{ Leaves number } & \multicolumn{4}{|c|}{ clusters number } \\
\hline & $\begin{array}{c}1^{\text {st }} \\
\text { season }\end{array}$ & \multicolumn{2}{|c|}{$\begin{array}{c}2^{\text {nd }} \\
\text { season }\end{array}$} & \multicolumn{2}{|c|}{$\begin{array}{c}1^{\text {st }} \\
\text { season }\end{array}$} & \multicolumn{2}{|c|}{$\begin{array}{c}2^{\text {nd }} \\
\text { season }\end{array}$} & \multicolumn{2}{|c|}{$\begin{array}{c}1^{\text {st }} \\
\text { season }\end{array}$} & \multicolumn{2}{|c|}{$\begin{array}{c}\text { 2nd } \\
\text { Season }\end{array}$} \\
\hline & 52.00 & 55.16 & $\mathrm{f}$ & 32.67 & $\mathrm{e}$ & 34.67 & $\mathrm{e}$ & 12.67 & $\mathrm{f}$ & 12.83 & $\mathrm{e}$ \\
\hline Humic acid & 64.67 & 71.29 & $\mathrm{~d}$ & 43.33 & $\mathrm{c}$ & 44.67 & $\mathrm{c}$ & 16.33 & $\mathrm{~cd}$ & 18.00 & $\mathrm{c}$ \\
\hline Fulvic acid & 60.67 & 66.71 & $\mathrm{de}$ & 40.67 & $\mathrm{~cd}$ & 42.67 & $\mathrm{~cd}$ & 15.00 & $\mathrm{de}$ & 15.67 & $\mathrm{~d}$ \\
\hline Calcium & 57.33 & 62.09 & ef & 37.00 & $\mathrm{~d}$ & 38.67 & $\mathrm{de}$ & 13.67 & ef & 14.67 & $\mathrm{de}$ \\
\hline $\mathrm{HA}+\mathrm{Ca}$ & \begin{tabular}{|l|}
70.67 \\
\end{tabular} & 77.21 & $\mathrm{c}$ & 47.67 & $\mathrm{~b}$ & \begin{tabular}{|l|}
50.67 \\
\end{tabular} & $\mathrm{~b}$ & 18.33 & $\mathrm{~cd}$ & 19.00 & $\mathrm{c}$ \\
\hline $\mathrm{FA}+\mathrm{Ca}$ & 63.67 & 70.21 & $\mathrm{~d}$ & 43.33 & $\mathrm{c}$ & 45.00 & $\mathrm{c}$ & 16.67 & $\mathrm{~cd}$ & 17.67 & $\mathrm{c}$ \\
\hline $\mathrm{HA}+\mathrm{F}$ & 80.00 & 86.64 & $\mathrm{~b}$ & 51.33 & $\mathrm{~b}$ & 54.33 & $\mathrm{~b}$ & 20.67 & $\mathrm{~b}$ & 21.67 & $\mathrm{~b}$ \\
\hline $\mathrm{HA}+\mathrm{F}+\mathrm{Ca}$ & 88.67 & 93.53 & $\mathrm{a}$ & 57.00 & $\mathrm{a}$ & 60.33 & $\mathrm{a}$ & 24.33 & $\mathrm{a}$ & 24.77 & $\bar{a}$ \\
\hline
\end{tabular}

Means followed in same column by similar letters are not statistically different at 0.05 levels according to Tukey test.

The effects of different treatments on nutrition status in tomato plants is illustrated in Table 5, data indicated that all foliar application treatments significantly increased all nutrients $(\mathrm{N}, \mathrm{P}, \mathrm{K}$ and $\mathrm{Ca})$ in the leaves. The highest concentration of $\mathrm{N}$ was found in humic plus fulvic acid plus calcium treatment 
compared to other treatments. Also, the highest concentration of $\mathrm{P}$ was found in humic plus fulvic acid plus calcium treatment. There were not significant differences with humic plus fulvic acid treatment. Besides, the maximum concentrations of $\mathrm{K}$ and $\mathrm{Ca}$ were preceded by humic plus fulvic acid plus calcium treatment. There were not significant differences with humic acid plus calcium treatment. These results are in harmony with those obtained by Ameri and Tehranifar (2012), they investigated that spraying of humic acid on strawberry plants enhanced nutrient uptake (N, P and K). Also, these results are in agreement with those obtained by Bethke et al. (1987) who reported that fulvic acid helps the plants to absorb other minerals and Yildirim and Unay (2011) who indicated that foliar application of fulvic acid and calcium with trace elements enhances the nutritional status of tomato plants.

TABLE 5. The effect of foliar application of HA, FA and Ca on nutrient content (N,P,K and Ca) of tomato plants during 2013 and 2014 seasons

\begin{tabular}{|c|c|c|c|c|c|c|c|c|c|}
\hline \multirow{3}{*}{ Treatments } & \multicolumn{2}{|c|}{$\mathbf{N}$} & \multicolumn{2}{|c|}{$\mathbf{P}$} & & \multicolumn{2}{|c|}{$\mathbf{K}$} & \multicolumn{2}{|c|}{$\mathrm{Ca}$} \\
\hline & \multicolumn{9}{|c|}{$\%$} \\
\hline & $\begin{array}{c}1^{\text {st }} \\
\text { season }\end{array}$ & $\begin{array}{c}2^{\text {nd }} \\
\text { season }\end{array}$ & $\begin{array}{c}1^{\text {st }} \\
\text { season }\end{array}$ & $\begin{array}{c}2^{\text {nd }} \\
\text { seasor }\end{array}$ & & $\begin{array}{c}1^{\text {st }} \\
\text { season }\end{array}$ & $\begin{array}{c}2^{\text {nd }} \\
\text { season }\end{array}$ & $\begin{array}{c}1^{\text {st }} \\
\text { season }\end{array}$ & $\begin{array}{c}2^{\text {nd }} \\
\text { season }\end{array}$ \\
\hline Control & 2.40 & $2.44 \mathrm{~g}$ & $0.338 \mathrm{f}$ & 0.464 & 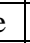 & $2.33 \mathrm{e}$ & $2.37 \mathrm{~d}$ & $0.95 \mathrm{e}$ & $1.10 \mathrm{f}$ \\
\hline Humic acid & $3.20 \mathrm{~cd}$ & $3.46 \mathrm{~cd}$ & $0.740 \mathrm{bc}$ & 0.782 & c & $3.28 \mathrm{bc}$ & $3.44 \quad b$ & $1.58 \mathrm{~d}$ & $1.66 \mathrm{e}$ \\
\hline Fulvic acid & $2.90 \mathrm{~cd}$ & $3.11 \mathrm{e}$ & $\begin{array}{|ll|}0.667 & \mathrm{~d} \\
\end{array}$ & 0.755 & c & $2.67 \mathrm{~d}$ & $2.87 \mathrm{c}$ & $1.48 \mathrm{~d}$ & $1.56 \mathrm{e}$ \\
\hline Calcium & 2.63 ef & $2.84 \mathrm{f}$ & $0.541 \mathrm{e}$ & 0.625 & $d$ & $3.13 \mathrm{c}$ & $3.38 \mathrm{~b}$ & $2.19 \mathrm{~b}$ & $2.29 \mathrm{c}$ \\
\hline $\mathrm{HA}+\mathrm{Ca}$ & $3.43 \mathrm{bc}$ & $3.63 \mathrm{bc}$ & $0.770 \mathrm{~b}$ & 0.835 & 0 & $3.46 \mathrm{ab}$ & $3.76 \quad \mathrm{a}$ & $2.38 \mathrm{ab}$ & $2.54 \mathrm{ab}$ \\
\hline $\mathrm{FA}+\mathrm{Ca}$ & $3.13 \mathrm{~cd}$ & $3.35 \mathrm{de}$ & $0.697 \mathrm{~cd}$ & 0.775 & $c$ & $3.27 \mathrm{bc}$ & $3.48 \quad b$ & $2.26 \mathrm{~b}$ & $2.38 \mathrm{bc}$ \\
\hline $\mathrm{HA}+\mathrm{F}$ & $3.67 \mathrm{bc}$ & $3.88 \mathrm{~b}$ & $0.840 \quad \mathrm{a}$ & 0.903 & 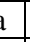 & $3.32 \mathrm{bc}$ & $3.51 \quad b$ & $\begin{array}{|ll|}1.86 & \mathrm{c} \\
\end{array}$ & $1.96 \mathrm{~d}$ \\
\hline $\mathrm{HA}+\mathrm{F}+\mathrm{Ca}$ & 4.09 & $4.23 \quad \mathrm{a}$ & $0.857 \mathrm{a}$ & 0.917 & $a$ & $3.65 \mathrm{a}$ & $\begin{array}{ll}3.87 & \mathrm{a} \\
\end{array}$ & $2.55 \quad \mathrm{a}$ & $2.62 \quad \mathrm{a}$ \\
\hline
\end{tabular}

Means followed in same column by similar letters are not statistically different at 0.05 level according to Tukey test.

The effects of different treatments on total yield and blossom end rot incidence in tomato fruits are showed in Table 6 the obtained results revealed that all spraying treatments of humic, fulvic acid and calcium significantly increased yield of tomato plants in comparison with untreated plants. Using third combination of humic, fulvic acid and calcium gave the highest value of total yield, while second combination of these solutions (humic plus fulvic acid, humic acid plus $\mathrm{Ca}$ and fulvic acid plus $\mathrm{Ca}$ ) came in the second position in this respect, whereas individual treatments (humic acid, fulvic acid and $\mathrm{Ca}$ ) came in the third position, finally untreated plants gave the lowest yield. These results are supported by Hosseini Farahi et al. (2013) they suggested that foliar application of humic acid led to improvement of quantitative and qualitative characteristics of tomato and strawberry, respectively. On the another hand, Peyvast et al. (2009) reported that foliar application of calcium could increase yield of tomato. Also, Yildirim and Unay (2011) indicated that foliar application of fulvic acid and calcium with trace elements enhanced the yield of tomato. As well, Osman et al.

Egypt. J. Soil Sci. 56, No. 3 (2016) 
(2013) mentioned that foliar application of humic and fulvic acid together increased rice yield and its components.

TABLE 6. The effect of foliar application of HA, FA and Ca on total yield and blossom end rot in fruits of tomato during 2013 and 2014 seasons

\begin{tabular}{|c|c|c|c|c|c|c|c|c|}
\hline \multirow{3}{*}{$\begin{array}{l}\text { Treatments } \\
\text { Control }\end{array}$} & \multicolumn{4}{|c|}{ (Ton/feddan) Total yield } & \multicolumn{4}{|c|}{ Blossom end rot (\%) } \\
\hline & \multicolumn{2}{|c|}{$\begin{array}{c}\text { 1st } \\
\text { season }\end{array}$} & \multicolumn{2}{|c|}{$\begin{array}{c}\text { 2nd } \\
\text { season }\end{array}$} & \multicolumn{2}{|c|}{$\begin{array}{c}\text { 1st } \\
\text { season }\end{array}$} & \multicolumn{2}{|c|}{$\begin{array}{c}\text { 2nd } \\
\text { season }\end{array}$} \\
\hline & 27.11 & $\mathrm{~h}$ & 27.83 & $\mathrm{f}$ & 32.00 & $\mathrm{a}$ & 33.67 & $\mathrm{a}$ \\
\hline Humic acid & 31.32 & $\mathrm{e}$ & 33.33 & $\mathrm{~cd}$ & 14.00 & $\mathrm{cb}$ & 15.00 & bc \\
\hline Fulvic acid & 30.49 & $\mathrm{f}$ & 31.83 & $\mathrm{~d}$ & 16.33 & $\mathrm{~b}$ & 17.00 & $\mathrm{~b}$ \\
\hline Calcium & 28.61 & $\mathrm{~g}$ & 29.67 & $\mathrm{e}$ & 6.67 & $\mathrm{~d}$ & 7.00 & $\mathrm{~d}$ \\
\hline $\mathrm{HA}+\mathrm{Ca}$ & 33.53 & $\mathrm{c}$ & 35.17 & $\mathrm{~b}$ & 5.67 & $\mathrm{~d}$ & 5.67 & $\mathrm{~d}$ \\
\hline $\mathrm{FA}+\mathrm{Ca}$ & 32.12 & $\mathrm{~d}$ & 33.67 & $\mathrm{bc}$ & 6.00 & $\mathrm{~d}$ & 6.50 & $\mathrm{~d}$ \\
\hline $\mathrm{HA}+\mathrm{F}$ & 34.71 & $\mathrm{~b}$ & 36.83 & $\mathrm{a}$ & 13.00 & $\mathrm{c}$ & 13.33 & $\mathrm{c}$ \\
\hline $\mathrm{HA}+\mathrm{F}+\mathrm{Ca}$ & 35.48 & $\mathrm{a}$ & 37.50 & $\mathrm{a}$ & 4.67 & $\mathrm{~d}$ & 5.00 & $\mathrm{~d}$ \\
\hline
\end{tabular}

Means followed in same column by similar letters are not statistically different at 0.05 level according to Tukey test.

Concerning the blossom end rot incidence in tomato fruits the results indicated that foliar application of humic, fulvic acid and calcium individual or in combination decreased the incidence of blossom end rot. All calcium treatments alone or in combination gave the lowest blossom end rot incidence in the fruits. These results agreed with that found by Kazemi (2013) who showed that foliar application of humic acid and Calcium alone or in combination decreased the incidence of blossom end rot in tomato fruits; with notice that the combination treatment was more effective than individual application. The blossom end rot of tomato fruit is a physiological disorder resulting from calcium deficiency (Del-Amor and Marcelis, 2003). It reduces fruit quality and market value (Taylor et al., 2004). The blossom end rot incidence can be aggravated by the deficiency of other nutrients such as $\mathrm{NH}_{4}-\mathrm{N}, \mathrm{K}$, and $\mathrm{Mg}$ (Navarro et al., 2005).

Concerning fruit characters of tomato, the results in Table 7 mentioned that fruit firmness, total soluble solid and vitamin $\mathrm{C}$ content of tomato fruits were increased significantly with all foliar application treatments individual or in combination, whereas titratable acidity in tomato fruits significantly was decreased in both seasons. The favorable fruit characters were obtained from plants that received the combination of humic, fulvic acid and calcium, while unfavorable effects on fruit quality were observed with untreated plants, whereas individual treatments were moderated. These results may be due to a positive effect of humic substances (humic and fulvic acid) that increase cell membrane permeability, respiration and photosynthesis in plant (Cacco \& Dell Agnolla, 1984, Russo \& Berlyn, 1990 and Fahramand et al., 2014). As well, they may be 
due to a benefit effect of calcium which has physiological and vital roles for development processes and fruit quality (Assmann, 1995; Marschner, 1995, Fallahi et al., 1997; Wojcik \& Lewandowski, 2003 and Reddy \& Reddy, 2004). These results are supported by the findings of Yildirim and Unay (2011) who found that foliar application of fulvic acid and calcium with trace elements enhance the yield and fruit quality of tomato. Also, these results are supported by Kazemi (2013) who reported that foliar application of humic acid and $\mathrm{Ca}$ alone or in combination improved yield and fruit quality of tomato with notice that the combination treatment was more effective than individual application.

TABLE 7. The effect of foliar application of HA, FA and Ca on fruit characters of tomato during 2013 and 2014 seasons.

\begin{tabular}{|c|c|c|c|c|c|c|c|c|}
\hline \multirow{2}{*}{ Treatments } & \multicolumn{2}{|c|}{$\begin{array}{l}\text { Fruit firmness } \\
\qquad \mathrm{g} / \mathrm{mm}^{2}\end{array}$} & \multicolumn{2}{|c|}{$\begin{array}{c}\text { TSS } \\
\%\end{array}$} & \multicolumn{2}{|c|}{$\begin{array}{c}\text { Titratable acidity } \\
\%\end{array}$} & \multicolumn{2}{|c|}{$\begin{array}{c}\text { V.C } \\
\text { Mg/100g }\end{array}$} \\
\hline & $\begin{array}{c}\text { 1st } \\
\text { season }\end{array}$ & $\begin{array}{c}\text { 2nd } \\
\text { season }\end{array}$ & $\begin{array}{c}\text { 1st } \\
\text { season }\end{array}$ & $\begin{array}{c}2^{\text {nd }} \\
\text { season }\end{array}$ & $\begin{array}{c}\text { 1st } \\
\text { season }\end{array}$ & $\begin{array}{c}\text { 2nd } \\
\text { season }\end{array}$ & $\begin{array}{c}\text { 1st } \\
\text { season }\end{array}$ & $\begin{array}{c}\text { 2nd } \\
\text { season }\end{array}$ \\
\hline Control & $44.00 \mathrm{f}$ & $27.83 \mathrm{f}$ & $4.70 \mathrm{~d}$ & $4.95 \mathrm{~d}$ & $2.86 \quad \mathrm{a}$ & $3.02 \mathrm{a}$ & $14.96 \mathrm{e}$ & $15.48 \mathrm{e}$ \\
\hline Humic acid & $50.33 \mathrm{~d}$ & $33.33 \mathrm{~cd}$ & $5.60 \mathrm{c}$ & $5.93 \mathrm{c}$ & $2.60 \mathrm{bc}$ & $2.67 \mathrm{~b}$ & $15.94 \mathrm{bc}$ & $16.51 \mathrm{bc}$ \\
\hline Fulvic acid & 47.33 e & $31.83 \mathrm{~d}$ & $5.47 \mathrm{c}$ & $5.77 \mathrm{c}$ & $2.64 \mathrm{bc}$ & $2.71 \mathrm{~b}$ & $15.69 \mathrm{~cd}$ & $16.23 \mathrm{~cd}$ \\
\hline Calcium & $53.33 \quad \mathrm{c}$ & $29.67 \mathrm{e}$ & $5.63 \mathrm{c}$ & $5.94 \mathrm{c}$ & $2.60 \mathrm{bc}$ & $2.64 \mathrm{~b}$ & $15.56 \mathrm{~d}$ & $16.09 \mathrm{~d}$ \\
\hline $\mathrm{HA}+\mathrm{Ca}$ & $56.00 \mathrm{~b}$ & $35.17 \mathrm{~b}$ & $6.53 \mathrm{~b}$ & $6.94 \mathrm{ab}$ & $2.54 \mathrm{bc}$ & $2.68 \mathrm{~b}$ & $16.20 \mathrm{ab}$ & $16.76 \mathrm{ab}$ \\
\hline $\mathrm{FA}+\mathrm{Ca}$ & $54.67 \mathrm{bc}$ & $33.67 \mathrm{bc}$ & $5.97 \mathrm{bc}$ & $6.29 \mathrm{bc}$ & $2.60 \mathrm{bc}$ & $2.74 \mathrm{~b}$ & $15.97 \mathrm{bc}$ & $16.56 \mathrm{bc}$ \\
\hline $\mathrm{HA}+\mathrm{F}$ & $50.67 \mathrm{~d}$ & 36.83 a & $6.07 \mathrm{bc}$ & $6.33 \mathrm{bc}$ & $2.55 \mathrm{bc}$ & $2.69 \mathrm{~b}$ & 16.43 a & 16.99 a \\
\hline $\mathrm{HA}+\mathrm{F}+\mathrm{Ca}$ & 58.67 a & $37.50 \mathrm{a}$ & $7.40 \quad \mathrm{a}$ & $7.67 \quad \mathrm{a}$ & $2.52 \mathrm{c}$ & $2.35 \mathrm{c}$ & $16.52 \mathrm{a}$ & $17.09 \mathrm{a}$ \\
\hline
\end{tabular}

Means followed in same column by similar letters are not statistically different at 0.05 level according to Tukey test.

\section{Conclusion}

In conclusion, foliar application of humic, fulvic acid and calcium individual or in combination improved vegetative growth parameters, yield and fruit quality of tomato; with a decrease in the fruits incidence of blossom end rot. The combination treatments were the most effective.

\section{References}


Ameri, A. and Tehranifar, A. (2012) Effect of humic acid on nutrient uptake and physiological characteristic Fragaria ananassa var. Camarosa. J. Biol. Environ. Sci., 6, 77-79.

AOAC (2005) Association of Official Agricultural Chemists. Official Methods of Analysis, $18^{\text {th }}$ ed. AOAC-Int., Arlington, VA.

Assmann, S.M. (1995) Cyclic AMP as a second messenger in higher plants. Pl. Physiol., 108, $885-889$.

Bethke, A.J., Parrella, M.P., Trumble, J.T. and Toscano, N.C. (1987) Effect of tomato cultivar and fertilizer regime on the survival of Liriomyza trifolii (Diptera: Agromyzidae). J. Econ. Entomol. 80, 200-203.

Brownell, J.R., Nordstrom, G. Marihart, J. and Jorgrnsen, G. (1987) Crop responses from two new leonardite extracts. Sci. Total Environ. 62, 491-499.

Cacco, G. and DellAgnolla, G. (1984) Plant growth regulator activity of soluble humic substances. Can. J. Soil Sci., 64, 25-28.

Christman, R.F. and Gjessing, E.T. (1983) Aquatic and terrestrial humic materials, The Butterworth Grove, Kent, England: Ann Arbor Science.

Cottenie, A., Verloo, M., Kiekers, L., Velghe, G. and Camrbynek, R. (1982) Chemical Analysis of Plants and Soils. Hand Book, 1-63, Ghent, Belgium.

Del-Amor, F.K. and Marcelis, L.F.M. ( 2003) Regulation of nutrient uptake, water uptake and growth under calcium starvation and recovery. J. HortScience Biotechnol., 78, 343-349.

Fahramand, M., Moradi, H., Noori, M., Sobhkhizi, A., Adibian, M., Abdollahi, S. and Rigi K. (2014) Influence of humic acid on increase yield of plants and soil properties. Intl. J. Farm. \& Alli. Sci., 3(3), 339-341.

Fallahi, E., Conway, W.S., Hickey, K.D. and Sams, C.E. (1997) The role of calcium and nitrogen in postharvest quality and disease resistance of apples. HortScience, 32(5), 831-835.

FAO (Food and Agriculture Organization) (1980) Soil and Plant Analysis. Soils Bulletin 38/2,250.

HosseiniFarahi, M., Aboutalebi, A. Eshghi, S., Dastyaran, M. and Yosefim, F. (2013) Foliar application of humic acid on quantitative and qualitative characteristics of 'Aromas' strawberry in soilless culture. Agri. Commun, 1, 13-16.

Jackson, W.R. (1993) Humic, fulvic, and microbial balance: Organic soil conditioning: An Agricultural Text and Reference Book, Jacks. Res. Cent., 958pp.

Jones, J.B. (2008) Tomato Plant Culture: In: The Field, Greenhouse and Home Garden ( $2^{\text {nd }}$ ed., p. 322). Boca Raton, Florida: CRC Press LLC. 
Karakurt, Y., H. Unlu and Padem, U. (2009) The influence of foliar and soil fertilization of humic acid on yield and quality of pepper. Acta Agr. Scand B-SP 59, 233-237.

Kazemi, M. (2013) Vegetative and reproductive growth of tomato plants affected by calcium and humic acid. Bull. Env. Pharmacol. Life Sci., 2(11), 24-29.

Khang, V.T. (2011) Fulvic foliar fertilizer impact on rice and radish at first stage. Omonrice, 18, 144-148.

Marschner, H. (1995) Mineral Nutrition of Higher Plants $\left(2^{\text {nd }}\right.$ ed.). Academic Press. New York. pp: 243-244.

McCarly, P. (1985) Humic substances in soil and crop sciences: selected readings. Proceedings of a symposium cosponsored by the International Humic Substances Society. Chicago, Illinois. December 2, 1985.

Ministry of Agriculture and Land Reclamation (EAS) Economic Affairs Sector 2013. Bulletin of Agriculture Statistics.

Ministry of Agriculture and Land Reclamation (2009) Symptoms of Nutrient Deficiency on Some Field and Horticultural Crops. Soils, Water and Environment Research Institute, Agricultural Research Center.

Navarro, J.M., Flores, P. Carvajal, M. and Martinez, V. (2005) Changes in quality and yield of tomato fruit with ammonium, bicarbonate and calcium fertilization under saline conditions. J. HortScience Biotechnol., 80, 351-357.

Osman, E.A.M., EL-Masry, A.A. and Khatab, K.A. (2013) Effect of nitrogen fertilizer sources and foliar spray of humic and/or fulvic acids on yield and quality of rice plants. Adv. Appl. Sci. Res., 4(4), 174-183.

Pardoe, H.L., Townshend, A., Clerc, J.T. and VenderLinden, (1990) Analytica Chimica Acts, Special Issue, Humic and Fulvic Compounds, 232 (1), 1-235.

Peyvast, G., Olfati, J.A. Kharazi, P.R. and Shahmaleki, S.K. (2009) Uptake of calcium nitrate and potassium phosphate from foliar fertilization by tomato. J. Hort. For., 1(1), 7-13.

Qassim, A. and Ashcroft, B. (2002) Estimating Vegetable Crop Water use with Moisture-Accounting Method \# AG1192, DPI Victoria. Available at: http://www.dpi.vic.gov.au/agriculture/horticulture/vegetables/vegetable-growing-andmanagement/estimating-vegetable-crop-water-use

Reddy, V.S. and Reddy, A.S.N. (2004) Proteomics of calcium-signaling components in plants. Phytochemistry, 65, 1745-1776.

Russo, R.O. and Berlyn, G.P. (1990) The use of organic biostimulants to help low input sustainable agriculture. J. Sustain, Agric., 1,19-42. 
Taylor, M.D., Locascio, S.J. and Alligood, M.R. (2004) Blossom end rot incidence of tomato as affected by irrigation quantity, calcium source, and reduced potassium. HortScience, 39, 1110-1115.

Wojcik, P. and Lewandowski, M. (2003) Effect of calcium and boron sprays on yield and quality of "Elsanta" strawberry. Journal of Plant Nutrition, 6, 671-682.

Yildrim, E. (2007) Foliar and soil fertilization of humic acid affect productivity and quality of tomato. Acta Agricultura Scandinavica, Section B - Soil \& Plant Science. 57,182-186

Yildirim, E.M. and Unay, A. (2011) Effects of different fertilizations on Liriomyza trifolii in tomato. Afr. J. Agric. Res., 6(17), 4104-4107.

(Received 2/8/2015;

accepted $3 / 10 / 2015)$

استجابة نباتات الطماطم للرش الورقى بحمض الهيوميك والفولفيك

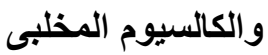

سعد أبو الحسن عبد العزيز 19 محمج الثربينى حسين2

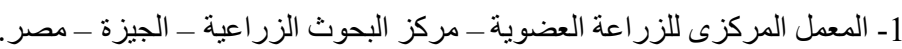

2- قسم الار اضى - كلية الزر اعة - جامعة القاهرة - الجيزة - مصر.

تم دراسة تاثير الرش الورقى بحمض الهيوميك وحمض الفولفيك والكالسيوم على (هيك

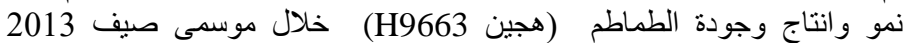

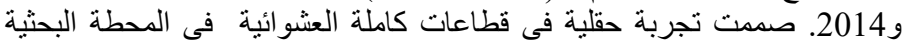

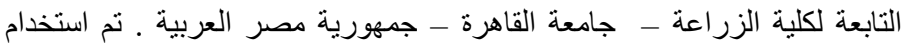

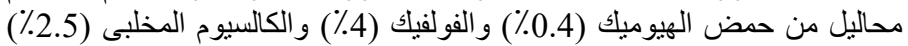

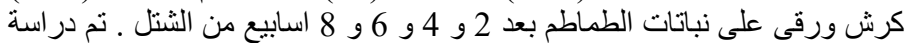

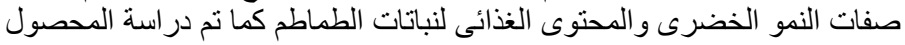

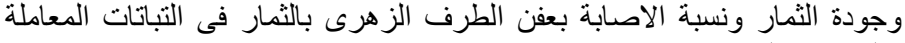
و الغير معاملة.

و اشارت النتائج الى ان الرش الورقى بحمض الهيوميك و الفولفيك و الكالسيوم

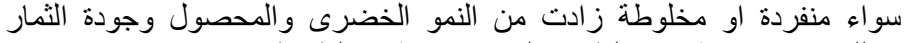

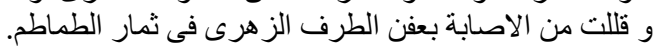

